\title{
“DEM WILLEN ZUM LEBEN IST DAS LEBEN GEWIB": VIDA E FINALIDADE EM SCHOPENHAUER
}

\author{
"DEM WILLEN ZUM LEBEN IST DAS LEBEN GEWIB": LIFE AND \\ PURPOSIVENESS IN SCHOPENHAUER ${ }^{l}$
}

\author{
WiLLIAM MATTIOLI ${ }^{2}$ \\ Universidade Federal do Rio de Janeiro (UFRJ) - Brasil \\ william.mattioli@gmail.com
}

\begin{abstract}
RESUMO: Neste artigo, pretendo discutir o problema da vida em Schopenhauer a partir da perspectiva de sua metafísica da natureza, que implica uma concepção teleológica da evolução das formas de manifestação da vontade segundo uma hierarquia de seus graus de objetivação. Meu ponto de partida é a fórmula schopenhaueriana mediante a qual o autor apresenta sua concepção básica acerca da essência de todo fenômeno: a "vontade de vida". Investigarei se e em que medida a noção de vida que encontramos em sua filosofia da natureza, a partir do conceito de "força vital" (Lebenskraft), o compromete ou ao menos o aproxima de uma posição que podemos chamar de vitalista, e isso com base na distinção entre três sentidos e graus de abrangência que podemos atribuir a uma tal posição: desde uma posição menos onerosa do ponto de vista metafísico e mais moderada no que diz respeito às suas pretensões, até uma posição mais radical, estrita, universalista e metafisicamente mais robusta. O trabalho que se segue é a primeira parte de um estudo sobre o problema da vida e da força vital em Schopenhauer, que será continuado numa segunda parte.
\end{abstract}

PALAVRAS-CHAVE: Schopenhauer. Vida. Força vital. Organismo. Vitalismo.

ABSTRACT: In this paper, I intend to discuss the problem of life in Schopenhauer from the perspective of his metaphysics of nature, which implies a teleological conception of the evolution of forms of manifestation of will according to a hierarchy of their degrees of objectification. My starting point is the Schopenhauerian formula by which the author presents his basic conception of the essence of every phenomenon: the "will to life". I will investigate if and to what extent the notion of life we find in his philosophy of nature, emerging from the concept of "vital force" (Lebenskraft), commits him or at least brings him closer to a position we can call vitalist, based on the distinction between three meanings and degrees of comprehensiveness that we can attribute to such a position: from a position less onerous from the metaphysical point of view and more moderate with respect to its pretensions, to a more radical, strict and universalist position,

\footnotetext{
${ }^{1}$ Este artigo corresponde à primeira de duas partes que perfazem um estudo sobre o problema da vida e do vitalismo em Schopenhauer. Uma segunda parte será publicada em breve como continuação do aqui exposto. O artigo correspondente levará o título: "O ventre enigmático da matéria': a concepção da vida na metafísica da natureza de Schopenhauer". Gostaria de agradecer a Jorge Prado pelas estimulantes discussões por ocasião do VIII Colóquio Internacional Schopenhauer, realizado em Curitiba entre 28/11 e 01/12/2017, onde apresentei um trabalho sobre a teleologia em Schopenhauer, e pela subsequente troca de e-mails. Parte da motivação para a elaboração do presente estudo se deve a essas conversas, e as reflexões que se seguem estão em continuidade com aquele trabalho sobre a teleologia, que foi publicado no volume: Schopenhauer: a filosofia e o filosofar (2018) e em versão substancialmente expandida no dossiê "Schopenhauer leitor de Kant" da Revista de Filosofia Aurora (cf. MATTIOLI, 2018).

2 Professor do Departamento de Filosofia da Universidade Federal do Rio de Janeiro (UFRJ).
} 
metaphysically more robust. The work that follows is the first part of a study on the problem of life and the concept of life force in Schopenhauer, which will be continued in a second part.

KEYWORDS: Schopenhauer. Life. Life force. Organism. Vitalism.

"À vontade de vida a vida é certa": essa sentença, formulada e repetida por Schopenhauer no contexto de suas reflexões sobre a morte e seu significado para a existência humana, traduz uma concepção da vida e de sua relação com a vontade, enquanto essência metafísica de tudo o que existe, em que a primeira é vista como desdobramento necessário da segunda, num sentido - poderíamos dizer - aparentemente quase finalista ou teleológico. A passagem do $\$ 54$ do quarto livro do Mundo que antecede a formulação acima dá boas indicações para pensarmos essa relação:

A vontade que, considerada puramente em si, destituída de conhecimento, é apenas um ímpeto cego e irresistível - como a vemos aparecer na natureza inorgânica e na natureza vegetal, assim como na parte vegetativa de nossa própria vida - atinge, pela entrada em cena do mundo como representação desenvolvida para seu serviço, o conhecimento de sua volição e daquilo que ela é e quer, a saber, nada senão este mundo, a vida, justamente como esta existe. Por isso denominamos o mundo fenomênico seu espelho, sua objetidade; e, como o que a vontade sempre quer é a vida, precisamente porque esta nada é senão a exposição daquele querer para a representação, é indiferente e tão-somente um pleonasmo se, em vez de simplesmente dizermos "a vontade", dizemos "a vontade de vida". (MVR I, p. 357s.). ${ }^{3}$

Fernando de Sá Moreira (2011, p. 48s.), em artigo em que trata justamente do tema que nos interessa aqui, se debruça sobre essa passagem e argumenta que ela sugere uma "coincidência entre os conceitos de vontade metafísica e vida". Sua tese, contudo, será a de que essa coincidência é apenas aparente e que devemos fazer uma distinção clara entre os sentidos destes respectivos conceitos no pensamento de Schopenhauer, sendo a vida um mero fenômeno da vontade, restrito ao âmbito do orgânico, não podendo ser expandido para o inorgânico (como seria sugerido pelo vitalismo), e tampouco podendo assumir uma conotação metafísica (MOREIRA, 2011, p. 50s.). Concordo parcialmente com a leitura de Moreira e, por mais que considere que ele tenha razão ao insistir na impossibilidade de se pensar o inorgânico, segundo as reflexões de Schopenhauer, como dotado de vida em sua expressão plena, buscarei argumentar que o filósofo pode sim ser considerado um vitalista ao menos num sentido restrito ou

\footnotetext{
${ }^{3}$ As referências à obra de Schopenhauer seguem o seguinte padrão: MVR = O mundo como vontade e representação, seguido do número do tomo e da paginação da tradução brasileira de Jair Barboza; CK = Crítica da filosofia kantiana, seguido da paginação da tradução de Jair Barboza; VN = Sobre a vontade na natureza, seguido da paginação da tradução brasileira de Gabriel Valladão Silva; PP = Parerga e paralipomena, seguido da paginação da edição de Paul Deussen que consta em Schopenhauer im Kontext (as traduções dos Parerga são de minha autoria).
} 
moderado. ${ }^{4}$ Não pretendo apresentar uma discussão exaustiva sobre o tema, mas indicar uma forma de compreender a relação entre vida, vontade e mundo que nos permita, em primeiro lugar, conceber a vida como um princípio irredutível (o que fica claro no conceito de "força vital" e, a meu ver, já posiciona Schopenhauer no interior de um vitalismo moderado) e, em segundo lugar, ver todo o existente como atravessado por um princípio vital que encontrará sua manifestação plena de modo progressivo na vida orgânica e, por fim, na vida humana.

Retornando à citação acima, há dois pontos que gostaria de sublinhar: em primeiro lugar, o significado da fórmula Wille zum Leben (vontade de vida); em segundo, o significado da metáfora do espelho, que é retomada na sequência nos seguintes termos:

Como a vontade é a coisa em si, o conteúdo íntimo, o essencial do mundo, e a vida, o mundo visível, o fenômeno, é seu espelho, segue-se daí que este mundo acompanhará a vontade tão inseparavelmente quanto a sombra acompanha o corpo. Onde existe vontade, existirá vida, mundo. Portanto, à vontade de vida a vida é certa. (MVR I, p. 358).

Esses dois pontos são, de certo modo, inseparáveis, e buscarei explicitar em que sentido o significado da fórmula Wille zum Leben e o significado da metáfora do espelho devem ser analisados conjuntamente. Isso nos permitirá compreender melhor as alternativas disponíveis no que diz respeito a uma interpretação finalista ou teleológica da fórmula em questão, por vezes apresentada na expressão alternativa Lebenwollen (querer-viver) (cf. MVR I, p. 412 e MVR II, p. p. 290s.).

Notemos então que, na própria estrutura sintática e semântica daquela fórmula conceitual: "Wille zum Leben", a vida aparece como o objeto intencional do querer (com a preposição " $z u$ " indicando justamente a direção ou meta do querer). Nesse sentido, a vida seria o fim (Zweck) do movimento ou atividade da vontade, segundo um esquema básico de orientação finalista. Além de algumas passagens de Sobre a vontade na natureza sugerirem essa leitura ${ }^{5}$, o conjunto de

\footnotetext{
${ }^{4}$ Moreira (2011, p. 50s.) afirma que Schopenhauer não é um "vitalista completo". Contudo, não fica claro, a partir de seus argumentos, o que seria um vitalismo, digamos, "incompleto", e se poderíamos compreender de modo consequente as posições de Schopenhauer como uma defesa de uma tal posição. Uma indicação de que essa talvez seja sua leitura nos é dada com a afirmação de que o filósofo "assume uma posição intermediária entre um fisicismo completo e um vitalismo completo" (MOREIRA, 2011, p. 51). Cacciola (2015, p. 41) recusa igualmente a atribuição a Schopenhauer de uma posição vitalista, com base na delimitação clara entre orgânico e inorgânico que encontramos em sua filosofia da natureza. Rudolf Malter (1983b, p. 49), por sua vez, parece atribuir ao filósofo uma tal posição, ao argumentar que a recusa do vitalismo por parte da pesquisa empírica no ramo da biologia atual representa um problema para o anseio schopenhaueriano de ter suas concepções comprovadas pela investigação positiva das ciências naturais. De minha parte, buscarei distinguir aqui, mesmo sem uma discussão devidamente aprofundada deste tópico, três sentidos em que podemos entender uma posição vitalista, de modo a compreender melhor em que sentido Schopenhauer pode ser considerado um defensor de uma tal visão de mundo: desde uma posição menos onerosa do ponto de vista metafísico e mais moderada no que diz respeito às suas pretensões, até uma posição mais radical, estrita, universalista e metafisicamente mais robusta.

${ }^{5}$ Cf. por exemplo VN, p. 107: "Tanto o ajustamento preciso da constituição às finalidades e relações vitais do animal, aqui exposto na estrutura óssea, como também a tão admirável adequação e harmonia de seu mecanismo interno não são nem de longe tornados tão compreensíveis por nenhuma explicação ou suposição que não a verdade já estabelecida anteriormente, segundo a
} 
reflexões sobre a teleologia no âmbito da filosofia da natureza do autor parece convergir para este ponto: se, por um lado, todo aspecto funcional do organismo responde à demanda de manutenção de sua vida, o que corresponde aos processos de objetivação da vontade no sentido de uma afirmação do querer-viver, por outro, todo o mundo inorgânico se ajusta e se adequa, como que antecipando a entrada no fenômeno das ideias que se encontram acima na hierarquia dos graus de objetivação da vontade (MVR I, p. 226s.), de modo a criar as condições necessárias para o surgimento e o desenvolvimento da vida em graus cada vez mais elevados ${ }^{6}$.

Em alguns fragmentos póstumos, discutidos por Brandão em seu importante livro: A concepção de matéria na obra de Schopenhauer (2008), o filósofo se apropria da noção aristotélica de enteléquia para pensar o princípio da efetividade das coisas em geral, remetendo-o, num primeiro nível, à noção de forma substantialis, em geral identificada à ideia platônica tal como ele a compreende (isto é, como grau de objetivação da vontade), ${ }^{7}$ e, num segundo nível, à própria vontade. Schopenhauer é claro quanto à sua compreensão da enteléquia como princípio de consumação de uma finalidade interna a uma determinada totalidade

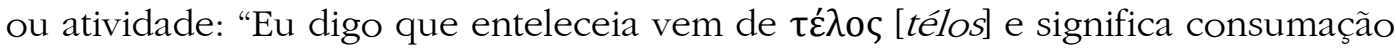
[Vollendung]". Brandão (2008, p. 71) argumenta que a interpretação dada por Schopenhauer à noção aristotélica remete à teleologia presente no segundo livro do Mundo, e cita então um outro trecho, extraído das Vorlesungen sobre a Metafísica da natureza: "A expressão forma substantialis deve ter sido usada primeiro por Averrores; mas o conceito é mais antigo: Aristóteles expressa o mesmo através de $\varepsilon v \tau \varepsilon \lambda \varepsilon ́ \chi \varepsilon\left\llcorner\alpha\right.$ (forma acabada)". ${ }^{9}$ Nesse último trecho, a associação entre enteléquia e forma substancial tem como resultado a atribuição de uma função télica à ideia: ela assume o papel de princípio formal e intencional que determina toda teleologia do mundo natural, estabelecendo como "fim" a expressão plena de sua forma nos fenômenos. Por fim, ainda acompanhando o encadeamento de trechos citados por Brandão, temos a seguinte passagem dos Nachlaß, onde a enteléquia é remetida diretamente à vontade como o princípio da realidade: "A $\dot{\varepsilon} v \tau \varepsilon \lambda \varepsilon_{\chi} \chi \varepsilon\llcorner\alpha$ de Aristóteles é o princípio da realidade [Realität], o outorgante da efetividade [Wirklichkeit] das coisas, em virtude da qual elas têm efetividade, realidade - em oposição a tudo meramente possível [...] para mim, a Vontade é a Entelechie de cada coisa". ${ }^{10}$ Assim, se na passagem anterior a enteléquia é associada à forma substancial ou à ideia, aqui ela é remetida à própria vontade; uma remissão tanto mais consequente na medida em que temos em mente dois pontos: em primeiro lugar, que a ideia não é outra coisa que um ato da vontade e, nesse sentido, é o princípio formal e intencional da atividade desta última; em segundo lugar, que, assim como a ideia corresponde à unidade

qual o corpo do animal nada mais é que sua própria vontade intuída como representação, e portanto no cérebro, sob as formas do espaço, do tempo e da causalidade - ou seja, mera visibilidade, objetidade da vontade. Pois sob essa pressuposição tudo nele deve conspirar à finalidade última, a vida desse animal".

${ }^{6}$ Remeto o leitor aqui ao meu artigo sobre a questão da teleologia em Schopenhauer (MATTIOLI, 2018), onde discuto de forma mais detida essas questões.

${ }^{7}$ Cf. por exemplo MVR I, p. 206s.; MVR I, p. 284s.; VN, p. 108; e, por fim, o $\$ 6$ dos Fragmentos sobre a história da filosofia (PP II, p. 63).

${ }^{8}$ Nachlaß III, p. 123, apud BRANDÃO, 2008, p. 71 (com uma pequena alteração na tradução).

9 Vorlesungen, Metaphysik der Natur, p. 134, apud BRANDÃO, 2008, p. 71.

${ }^{10}$ Nachlaß IV, 1, p. 245, apud BRANDÃO, 2008, p. 71s. 
inteligível de toda a pluralidade de fenômenos que recaem sob seu escopo e da interconexão e desenvolvimento de suas partes, a vontade corresponde à unidade inteligível da totalidade da natureza e da relação dinâmica das partes dessa última. Tudo isso se encontra muito bem exposto no parágrafo 28 do primeiro tomo do Mundo e no capítulo 26 dos Complementos.

As indicações de Brandão e sua apresentação dos débitos de Schopenhauer com relação a Aristóteles são preciosas, ${ }^{11}$ e o que nos interessa aqui em especial é chamar atenção tanto para a associação direta entre vontade e enteléquia, quanto, na esteira dessa associação, para o caráter teleológico da atividade da vontade por trás da produção de cada ente natural. Ora, é importante lembrar que a finalidade ou conformidade a fins é, pelo menos num primeiro momento, o princípio que estabelece a especificidade dos fenômenos da vida, na medida em que esta se manifesta num tipo especial de ente natural: o organismo, cuja organização não pode ser explicada por remissão à mera causalidade mecânica. Nisso, Schopenhauer segue os mesmos passos de Kant, quando este reconhece, na unidade autorreguladora do organismo, em que as partes só são "possíveis por sua relação com o todo" e se ligam "à unidade de um todo em virtude de serem reciprocamente causas e efeitos umas das outras" (CFJ, p. 373), um tipo específico de causalidade. É essa causalidade que Schopenhauer remeterá explicitamente à causa final aristotélica, em alguns textos nos quais que lida diretamente com o tema da teleologia (cf. MVR II, p. 400; PP II, p. 149).

Ora, mas se é verdade que o princípio da finalidade serve, num primeiro momento, para dar conta da especificidade dos fenômenos orgânicos, Schopenhauer o expande num segundo momento para a compreensão da totalidade da natureza e da relação entre todas as suas partes. O que temos aqui é uma analogia estrutural entre o que o autor chama de finalidade interna e finalidade externa. E isso porque o surgimento dos organismos pressupõe, do ponto de vista de sua produção material (biogênese), toda a história natural que o antecede e, portanto, todas as formas da natureza anteriores ao seu aparecimento, pois são elas que fornecem as condições materiais para sua produção segundo uma conjunção de causas e efeitos, que é pensada aqui como orientada por um princípio teleológico, assim como as partes do organismo trabalham conjuntamente para seu pleno desenvolvimento e para expressão acabada de sua forma substancial ou ideia. Trata-se aqui do "apoio" e da "ajuda" que todos os organismos "recebem de fora, tanto da natureza inorgânica quanto uns dos outros" (MVR I, p. 224). O que Schopenhauer tem em vista, nesse sentido, é que, assim como a ideia do organismo contém a unidade inteligível e paradoxalmente atemporal de todos os seus desenvolvimentos temporais, a unidade da vontade que se manifesta na totalidade da natureza contém em si a unidade inteligível de

\footnotetext{
${ }^{11}$ Cf. ainda seu comentário mais à frente no livro, em que retoma a referência a Aristóteles no contexto da discussão sobre o princípio da finalidade: "Tudo parece se passar como se a ideia de finalidade, relacionada à representação, carregasse a marca da Kant; e, vinculada ao em si, fosse estabelecida na esteira de Aristóteles - como vimos no primeiro capítulo, Schopenhauer associa a Vontade à entelékheia e esta a télos. Assim, a influência aristotélica na teoria dos graus de objetivação da Vontade é suficientemente assumida por Schopenhauer: tanto no que diz respeito à noção de ideia ou grau de objetivação da Vontade, quanto ao que nos interessa mais especificamente aqui: a noção de Materie" (BRANDÃO, 2008, p. 133). A relação entre o conceito de matéria e o aspecto finalista das reflexões de Schopenhauer em torno do processo de objetivação da vontade e, em especial, do problema da vida, será discutida na segunda parte deste estudo.
} 
todos os desenvolvimentos temporais de todas as suas partes, desde a natureza inorgânica até o ser humano. ${ }^{12}$ Nesse sentido, cada ato da vontade, enquanto produto daquela unidade inteligível, está orientado para a finalidade da vida, e em cada um desses atos devemos poder reconhecer um momento cada vez mais perfeito daquela mesma vida. ${ }^{13}$

De saída, vale destacar que a filosofia da natureza de Schopenhauer se encontra, assim, marcada por um gradualismo: a série evolutiva dos fenômenos da vontade se eleva lentamente das manifestações mais elementares às manifestações mais perfeitas daquela substância vital primeira, excluindo-se, ao menos a princípio, a possibilidade de saltos abruptos nesse processo evolutivo. Daí a recorrência, em seus textos, da sentença aristotélica: natura non facit saltus. ${ }^{14} \mathrm{E}$ verdade que, em certas passagens, o filósofo dá a entender que, em ocasiões específicas, a natureza realiza saltos qualitativos mais radicais. Dois trechos de sua obra, um do capítulo "Astronomia Física" de Sobre a vontade na natureza e outro do capítulo 23 dos Complementos ao Mundo: "Sobre a objetivação da vontade na natureza desprovida de conhecimento", chegam a caracterizar a fronteira entre o inorgânico e o orgânico e, portanto, o surgimento da vida em sentido estrito, como a fronteira mais bem traçada da natureza e até mesmo como uma possível exceção à fórmula aristotélica. ${ }^{15}$ Outras passagens, contudo, apontam na direção oposta, sugerindo que aquilo que caracteriza essencialmente a vida (a responsividade a estímulos e a sensibilidade animal), deve poder ser gradualmente expandido à totalidade da natureza (como análogos seus, cada vez mais despotencializados), de modo que, entre a cognição humana, a cognição animal, a receptividade a estímulos dos vegetais, as reações químicas dos materiais e os efeitos físicos e mecânicos dos movimentos dos corpos, devemos reconhecer distinções apenas de grau. ${ }^{16}$

Mas deixemos o tema do gradualismo de lado, no momento; ele será objeto de análise na segunda parte deste estudo. Retomemos a associação indicada acima entre a expressão teleológica da fórmula Wille zum Leben e a metáfora do espelho. A chave para a compreensão dessa relação é a tese schopenhaueriana acerca do autoconhecimento da vontade. Trata-se de uma de suas teses mais centrais,

${ }^{12}$ Cf. MVR I, \ 28. Discuto este ponto de forma mais detalhada em MATTIOLI, 2018, p. 226s.

${ }^{13}$ Esse talvez seja o ponto central de uma interpretação vitalista da metafísica de Schopenhauer que assuma uma pretensão mais universalista e, apesar de ela não ser a única interpretação vitalista possível, ela constituirá o fio condutor da argumentação geral que pretendo desenvolver nas duas partes deste estudo.

${ }^{14}$ Cf. em especial MVR II, p. 402, mas também MVR II, p. 671 e PP II, p. 168.

15 Cf. VN, p. 138s. e MVR II, p. 356. Sobre isso, cf. ainda SORIA, 2012 (em especial, p. 199s.) e ROCHA, SILVA E BAZZANELLA, 2017, p. 18s. (apesar de se tratar de um artigo em conjunto sobre o conceito de vida em Kant, Schopenhauer e Nietzsche, a parte sobre Schopenhauer é de responsabilidade de Silva, razão pela qual, no corpo do texto, me referirei somente a ele quando se tratar de discutir sua interpretação). Numa passagem do capítulo 5 do segundo tomo do Mundo, porém, a afirmação de que o salto entre o inorgânico e o orgânico é o maior da natureza é, se não claramente contradita, ao menos fortemente relativizada: "Entrementes, a lei natura non facit saltus não é inteiramente abolida, tampouco no caso do intelecto dos animais; embora o passo do intelecto animal ao humano tenha sido o mais amplo que a natureza deu na produção dos seus seres" (MVR II, p. 73, grifo nosso).

16 Cf. por exemplo MVR II, p. 339; VN, p. 123ss., p. 131s. e p. 222. Sobre isso, cf. ainda FRAUENSTÄDT, 1876, p. 182ss., KEUTEL, 1896, p. 27 e SILVA, 2015, p. 230ss. Me debruçarei mais detidamente sobre esse ponto na segunda parte deste estudo. 
segundo a qual "o mundo é autoconhecimento da vontade" (MVR I, p. 517), e que insere um tipo de paradoxo na estrutura teleológica da fórmula em questão. Vejamos como isso se dá.

\section{II}

Na medida em que se objetiva, se expressa, se manifesta (seja qual for o verbo que empreguemos para nos referirmos à "relação" sui generis entre a vontade e o mundo fenomênico), cada grau desse processo de objetivação representa um aumento no grau de visibilidade da vontade. Mas seu autorreflexo propriamente dito só entra em cena, ainda que de modo incipiente, com o surgimento do primeiro intelecto animal, que é capaz de traduzir cada ato daquela vontade metafísica numa representação mental, por mais primitiva que esta seja ${ }^{17}$. Por sua vez, essa tradução do mundo como vontade em representações mentais só se dá no âmbito da vida, como resposta do organismo às exigências do meio, que o obrigam a orientar seus movimentos segundo uma imagem sensível: o motivo. Com o aumento na capacidade do intelecto devido ao aumento na complexidade estrutural do cérebro, a imagem da vontade diante de si mesma torna-se cada vez mais clara, até que ela atinge seu ápice com o intelecto humano, sendo capaz de reconhecer-se a si mesma de modo pleno e enquanto tal: enquanto um ímpeto insaciável. Nesse sentido, a vida é um espelho da vontade, isto é, um meio para seu autoconhecimento.

Para Koßler (2012), isso não apenas torna problemático o conceito schopenhaueriano de vida, como o afasta das concepções mais tradicionais da Lebensphilosophie, às quais ele é eventualmente associado, na medida em que, nessas concepções, a vida é vista como um fim em si mesmo. Seria correto afirmar que a possibilidade de se atribuir a Schopenhauer uma posição vitalista depende da resposta que damos à questão se a vida é um fim em si mesmo ou meramente um fim relativo? E se, para o filósofo, "a vida é apenas um espelho", seria isso suficiente para responder negativamente à pergunta sobre um possível vitalismo em sua metafísica da natureza? Acredito que não, mas a justificativa para essa resposta depende, em primeiro lugar, do modo como compreendemos o que significa uma posição vitalista e da distinção entre os escopos de abrangência que acredito poderem ser associados a ela; em segundo lugar, de uma leitura determinada de alguns temas chave da filosofia da natureza de Schopenhauer, dentre eles: o problema do finalismo e da teleologia, o conceito de Lebenskraft, a noção de generatio aequivoca, a ambiguidade de sua concepção de matéria, a questão do gradualismo e a relação entre ideia e espécie. Nessa primeira parte de nosso estudo, focaremos nos dois primeiros temas. A segunda parte abordará mais detidamente os temas restantes.

Segundo a leitura que proponho aqui, o caráter problemático da posição do autor do Mundo acerca da vida e a tensão que nela se expressa, na medida em

${ }^{17}$ Cf. por exemplo MVR II, p. 346: "De fato, reconhecemos que a força interior da natureza, que originariamente é desprovida de conhecimento e impulsiona-se na escuridão, e que, quando atuou até alcançar a consciência de si, desvela-se a esta como vontade, só atinge esse grau por meio da produção de um cérebro animal, e do conhecimento como função deste, instante a partir do qual surge nesse cérebro o fenômeno do mundo intuitivo". 
que a vontade é definida como vontade de vida, ao mesmo tempo em que a vida não pode ser considerada um fim em si mesmo, é correlata à tensão que creio poder identificar, em sua filosofia, entre duas formas de teleologia que se encontram em permanente rota de colisão, e que denomino teleologia funcional e teleologia ético-soteriológica (cf. sobre isso MATTIOLI, 2018, p. 222ss). A teleologia funcional é aquela a partir da qual se pensa o desenvolvimento e a dinâmica das relações internas das partes dos organismos, assim como sua relação com o restante da natureza, como estando orientados primariamente para a produção, reprodução, manutenção e transmissão da vida e do princípio vital da espécie. Nessa forma de teleologia, a noção de "perfeição" é predicada de um organismo ou de um intelecto animal em função da adequação pragmática de suas formas a essa finalidade. Aqui, a fórmula Wille zum Leben encontra sua expressão teórica mais consistente. Mas não se trata de uma identificação conceitual entre vontade e vida ou de uma "completa coincidência entre os conceitos de vontade metafísica e vida", como sugere Moreira (2011, p. 49) ${ }^{18}$ ao apresentar uma das leituras possíveis das passagens citadas no início deste trabalho, da qual ele pretende se distanciar. Antes, segundo penso, a fórmula Wille zum Leben e a orientação teleológica que ela implica aponta para uma relação entre o princípio volitivo e o princípio vital na qual o último funciona como momento intencional do primeiro, vinculando sua atividade à necessidade de consumação daquilo que nele está contido em germe ou potência. Daí a importância da associação que faz Schopenhauer entre a atividade da vontade e a noção aristotélica de enteléquia.

Se partirmos da leitura de Barboza (2005), diremos que há, nessa teoria de Schopenhauer, ressonâncias não só de Aristóteles, mas também de Schelling, autor do qual o comentador extrai o conceito de "vida universal". Em sua leitura, a vontade schopenhaueriana, se não é idêntica, está ao menos muito próxima dessa noção. Não entrarei aqui numa discussão mais específica acerca da relação entre Schopenhauer e Schelling propriamente dita, mas acho elucidativo citar e comentar um importante trecho em que Barboza apresenta essa interpretação:

em que pese a crítica à unidade ideal-real da intuição intelectual, esta de fato remete em muitas passagens a uma anterioridade volitiva aos fenômenos, ou seja, a uma separação de duas dimensões do ser, intermediadas pelas Ideias. A função das Ideias na natureza tem de ser compreendida em conexão com o conceito de vida universal. Essa é, pode-se assim dizer, a 'infinitude subjetiva' de Schelling a que Schopenhauer se refere ${ }^{19}$ [...] A vontade como natura naturans, pura atividade que se afirma na natura naturata, é essencialmente de vida (zum Leben). Vida não no sentido de que o querer anseie por um viver exterior a si, intentando alcançá-lo, mas no sentido de algo intrínseco e que se confunde com ele na sua atividade incessante. É impossível, pois, separar ambos os termos. (BARBOZA, 2005, p. 122s.).

18 Silva (2017, p. 16s.) defende a mesma leitura, quando diz que, na perspectiva do que ele denomina "definição essencial" da vida em Schopenhauer, a partir da fórmula "Wille zum Leben", os conceitos de vontade e de vida seriam intercambiáveis.

${ }^{19}$ Barboza faz referência à seguinte passagem do Nachlass: "A infinitude objetiva é o resultado da filosofia dos eleatas, de Bruno (cf. em especial a exposição de seu uno em Jacobi sobre Espinosa) e de Espinosa. Ela está para a infinitude subjetiva como o corpo iluminado para o sol. Esta última é exposta especialmente no Upanixade, em Kant, no eu absoluto de Schelling. Espero pela primeira vez expô-la de modo puro" (SCHOPENHAUER, 1966-1975a, HN I, p. 142; apud BARBOZA 2005, p. 115). 
Notemos que, em seu comentário, Barboza sublinha a parte da expressão "vontade de vida" que designa sua orientação teleológica: zum Leben. Gostaria de sublinhar aqui também o advérbio "essencialmente", com o qual Barboza qualifica a modalidade dessa orientação teleológica. Nessa leitura, ela é, antes de mais nada, metafísica. Em sua essência própria, a vontade é uma vontade de vida, de modo que este princípio intencional lhe é ontologicamente inseparável. Barboza argumenta ainda que não se trata da vida entendida como algo ao qual a vontade ansiasse enquanto exterioridade, mas, antes, no sentido de um princípio que lhe é intrínseco. Essa leitura me parece acertada, contanto que distingamos o estatuto deste princípio na qualidade metafísica de atividade de uma potência, e seu estatuto enquanto realização fenomênica dessa potência em graus cada vez mais elevados. Como veremos - e Barboza traz à tona este ponto justamente na sequência da passagem acima citada -, a plena realização da vida se dá no momento em que ela se torna auto-espelhamento da vontade, ${ }^{20}$ e isso só é possível após toda a passagem pelos reinos inorgânico, vegetal e animal. Assim, ainda que a vida não se ligue à vontade como um princípio que lhe seja externo, é preciso distinguir o estatuto do conceito de vida enquanto princípio imanente da vontade no sentido metafísico, do estatuto deste conceito na medida em que ele se refere às manifestações desta vida nos fenômenos. ${ }^{21}$ Porém, não acredito que essa distinção possa ser pensada adequadamente como uma distinção entre sentido literal e sentido metafórico, como sugere Silva (2017, p. 22) ao buscar restringir o sentido literal do conceito à sua manifestação fenomênica nos vegetais e animais. Talvez possamos pensar numa distinção entre sentido estrito e sentido amplo do conceito $^{22}$, mas concordo com a afirmação de Philonenko (1980, p. 19) de que, quando se fala de uma "vida da natureza" (cf. MVR I, p. 359), não se trata meramente de uma metáfora, mas daquilo que indica a unidade própria do ser. Ademais, acredito ser possível distinguir não apenas dois, mas três sentidos referentes ao conceito de vida (que correspondem, como veremos, aos níveis de abrangência do vitalismo): um deles restrito ao orgânico e irredutível ao modelo de explicação mecânica; os dois outros ampliados e cuja determinação depende do alcance e do sentido que atribuímos ao expediente da argumentação analógica, que projeta na totalidade da natureza o princípio movente de nossa própria corporeidade.

$\mathrm{Na}$ segunda parte deste estudo, discutirei em mais detalhes o modo como acredito ser possível considerar universalmente este princípio vital a partir de suas manifestações no mundo por intermédio das ideias e da matéria. No momento, porém, precisamos retornar à segunda forma de teleologia indicada acima, que eu chamei de ético-soteriológica, e à qual a metáfora do espelho está mais diretamente associada. Trata-se de um outro registro de argumentação teleológica, no qual Schopenhauer pensa o desenvolvimento das formas de manifestação da vontade como orientado para a produção de um intelecto superior capaz justamente de se libertar, mediante sua capacidade reflexiva, daquela função pragmática à qual ele

\footnotetext{
${ }^{20}$ Cf. sobre isso MVR I, p. 357, onde Schopenhauer define a vida como a "exposição do querer para a representação".

${ }^{21}$ Este me parece ser um ponto de partida interessante e muito promissor para nos confrontarmos com a crítica que faz Nietzsche ao conceito schopenhaueriano de vontade de vida, sobretudo no Zaratustra. Pretendo me debruçar sobre essa questão num trabalho futuro. Uma discussão deste ponto se encontra em Decher (1984, em especial cap. III) e MOREIRA, 2015, p. 95ss.

${ }^{22}$ Cf. ROCHA, SILVA E BAZZANELLA, 2017, p. 17s. e MOREIRA, 2011, p. 60.
} 
está submetido no contexto da teleologia funcional, ou seja, um intelecto capaz de se libertar das necessidades e imposições da vontade, se elevando então ao conhecimento do imutável, isto é, tanto ao conhecimento das ideias como formas eternas a pairar livremente sobre a tormenta dos fenômenos, quanto ao conhecimento da vontade como unidade eterna e absoluta de tudo o que existe. Obviamente, esse tipo sui generis de conhecimento é prerrogativa do intelecto humano e somente é alcançado por indivíduos de capacidade reflexiva superior ${ }^{23}$, como o filósofo, o gênio e o santo. É nele que se dá então o pleno autoespelhamento da vontade, sua forma consumada de autoconhecimento. ${ }^{24}$

Retomando o argumento de Koßler (2012), tudo indica que a vida, enquanto espelho da essência volitiva da natureza, é, portanto, apenas um meio para o autoconhecimento da vontade, que seria o fim propriamente de seu anseio mais íntimo. Como afirma Schopenhauer no quarto livro do Mundo: "o mundo é autoconhecimento da vontade" (MVR I, p. 517). Quanto a isso, Koßler parece estar de acordo com a tese de Malter (1983a, p. 444) de que esse autoconhecimento seria a meta visada por todo o processo de objetivação. Malter, por sua vez, parece compreender essa meta do ponto de vista da própria vontade, e não meramente do mundo como representação. Segundo penso, é isso que está por trás do modo como Schopenhauer estabelece a hierarquia dos graus de objetivação da vontade, o que lhe permite falar em graus inferiores e superiores de objetivação e, até mesmo, no grau mais "perfeito", que corresponde ao intelecto humano. ${ }^{25}$ Assim, essa hierarquia dependeria da determinação de uma finalidade última no âmbito da soteriologia, já que "todo o mundo visível é apenas a objetivação, o espelho da vontade que a acompanha para o seu autoconhecimento" e, com isso, "para a possibilidade de sua redenção" (MVR I, p. 349). Isso se dá na medida em que o autoconhecimento da vontade a conduz à constatação de que ela mesma é a fonte de sua própria miséria e de todo sofrimento do mundo, e de que nenhuma satisfação e nenhuma paz neste mundo são possíveis (ATWELL, 1995, p. 153). Assim se realiza aquilo que Schopenhauer, em algumas passagens, chama de "fim da nossa existência" ou "sentido mais profundo da vida" (MVR II, p. 756): a autonegação da vontade resultante de seu pleno autoconhecimento.

É no contexto desse segundo registro de argumentação teleológica que encontramos algumas de suas mais importantes reflexões sobre a morte. Duas passagens se destacam nesse sentido, na medida em que vinculam a morte diretamente à noção de "fim" (Zweck). A primeira delas se encontra no parágrafo 49 do segundo tomo do Mundo:

A morte decerto deve ser considerada como o fim propriamente dito da vida: no momento em que a morte se dá, decide-se tudo o que no curso inteiro da vida fora apenas preparado e introduzido. A morte é o resultado, o resumé da vida, ou a soma final que expressa de uma vez todo o ensinamento que a vida dera parcial e fragmentariamente, a saber, que toda aspiração, cujo

\footnotetext{
${ }^{23}$ Schopenhauer se refere a essa capacidade reflexiva com o termo Besonnenheit.

${ }^{24}$ Cf. sobre isso MATTIOLI, 2018, p. 224s., p. 230s. e as referências ali indicadas.

25 Segundo me parece, a tese de que o intelecto humano representa o grau mais perfeito de objetivação e a consumação (Vollendung) do processo evolutivo das manifestações da vontade introduz na filosofia da natureza (e, portanto, na consideração da teleologia funcional), o ponto de vista da teleologia ética ou soteriológica (cf. MATTIOLI, 2018, p. 228s.).
} 
fenômeno é a vida, foi algo vão, fútil, contraditório consigo mesmo, e a ela renunciar consiste numa redenção. (MVR II, p. 758).

A segunda passagem, muito próxima da primeira, se encontra no texto "Especulação transcendente sobre a aparente intencionalidade no destino do indivíduo", dos Parerga, e se tornou famosa por ter sido referenciada por Freud como uma fonte importante de sua noção de "pulsão de morte" (Todestrieb) e de seu segundo dualismo pulsional, que opõe pulsão de vida e pulsão de morte: ${ }^{26}$

Assim, aquela direção invisível, manifesta apenas em aparência duvidosa, nos conduz até a morte, esse verdadeiro resultado e, nessa medida, verdadeiro fim (Zweck) da vida. Na hora da morte, todos os poderes misteriosos (apesar de enraizados verdadeiramente em nós mesmos) que determinam o eterno destino do homem se conjugam e entram em ação. De seu conflito se produz o caminho que ele deve agora percorrer, isto é, preparase sua palingenesia, junto com todo prazer e toda dor contidos nela e que agora o determinam inexoravelmente. (PP I, p. 250).

Não me deterei na discussão do tema da morte especificamente ${ }^{27}$; gostaria apenas de sublinhar que ambas as passagens tratam da morte como um "fim", tendo em vista, na verdade, um fim ainda mais elevado: a redenção através da negação da vontade. Zentner (1993, p. 326) parece ter razão ao argumentar que não se trata de entender a morte no sentido de uma finalidade inerente ao processo de objetivação da vontade, como uma espécie de fim biológico. Para o comentador, a noção de " $Z$ weck" deve ser compreendida, aqui, num sentido antes de mais nada ético. Do ponto de vista semântico, a referência é sobretudo ao sentido ou à significação moral que podemos atribuir à vida e à existência a partir da consciência, da experiência ou do momento da morte. E isso porque a morte se revela como um momento fundamental no processo de negação da vontade, como uma espécie de catalisador da redenção. Rigorosamente falando, portanto, a morte seria antes um meio do que um fim propriamente dito; ou, em outros termos, um fim submetido hierarquicamente a um fim superior devido ao seu potencial catalisador como quietivo da vontade. ${ }^{28}$

${ }^{26}$ Cf. sobre isso Zentner (1993) e Atzert (2005).

${ }^{27}$ Sobre o tema da morte, cf. também CACCIOLA, 2007, e GERMER, 2018 (que contesta, a meu ver insatisfatoriamente, a leitura de Zentner). Sobre a noção de "palingenesia", que aparece nesse texto, cf. ANTONIASSI, 2018.

${ }^{28}$ Quanto a isso, cf. MVR II, p. 756s.: "não há dúvida de que tudo na vida está disposto a nos [...] convencer que o fim da nossa existência não é sermos felizes. Sim, para quem a contempla nos detalhes e imparcialmente, a vida expõe-se antes como especialmente destinada a que não sejamos nela felizes, na medida em que a mesma, através de toda sua índole, porta o caráter de algo que nos estraga o gosto, que nos repugna, algo que temos de desistir como de um erro, para que o nosso coração seja salvo do vício de gozar, sim, de viver, e renuncie ao mundo. Nesse sentido, seria mais correto colocar o fim da vida antes em nossa dor e não no prazer. Pois [...] quanto mais se sofre, tanto mais se está perto de alcançar o verdadeiro fim da vida, e quanto mais feliz se vive, tanto mais distante fica esse fim. [...] Também o efeito peculiar da tragédia baseia-se no fundo em que ela rompe aquele erro inato [a crença de que existimos para sermos felizes, W.M.], na medida em que nos ilustra, num grande e vistoso exemplo, o fracasso das aspirações humanas e a vaidade de toda esta existência, revelando assim o sentido mais profundo da vida. [...] Ora, quem, por um ou outro caminho, saiu daquele erro a priori que nos é inerente [...] logo verá tudo sob uma luz 
Vinculada a essas reflexões, poderíamos falar numa caracterização da vida em termos existenciais ou éticos. ${ }^{29}$ Koßler afirma, nesse contexto, que não devemos "buscar o sentido e o objetivo da vida nela mesma, como ela se apresenta imediatamente [...], mas sim em uma interpretação (Deutung) dos fenômenos da vida, através da qual eles constituem um todo coerente." O que se tem em vista é que, diante da morte, "a experiência da miséria e da nulidade da vida deve produzir um sentido", que é, antes de mais nada, ético (KOßLER, 2012, p. 20).

Contudo, há dois pontos que gostaria de destacar com relação à leitura de Koßler, a partir dessas reflexões sobre a morte: 1) em primeiro lugar, se é verdade que a vida, para Schopenhauer, não deve ser vista como um fim em si mesmo, sendo apenas um espelho e, nesse sentido, um meio para o autoconhecimento da vontade, tampouco o autoconhecimento se configura, em última instância, como um fim em si mesmo. Na hierarquia dos fins de sua doutrina soteriológica, mesmo o autoconhecimento está submetido ao fim último da negação da vontade, que corresponde à redenção. Koßler reconhece claramente este ponto, o que sugere que, ao falar do autoconhecimento como "fim", ele deve ter em vista, na verdade, aquilo que é produzido por esse autoconhecimento, de modo que, assim como a vida, o autoconhecimento se converteria também em meio para um fim; 2) em segundo lugar, se estivermos corretos em estabelecer uma distinção entre dois registros de argumentação teleológica: o funcional e o ético-soteriológico, talvez possamos realocar a vida em posições distintas nesses dois registros. Nesse sentido, se é verdade que o autoconhecimento ocupa um lugar central no segundo registro, único no qual ele pode ser considerado relativamente como um fim, no primeiro ele está praticamente ausente, desempenhando apenas um papel indireto como diretriz implícita na argumentação em torno da hierarquia dos graus de objetivação da vontade. Assim, enquanto o segundo registro se desdobra em torno da ética da negação da vontade, o primeiro se desdobra em torno de uma filosofia da natureza que apresenta a evolução das formas de manifestação da vontade no sentido de sua afirmação. Com efeito, a tese de que a vida é uma manifestação da vontade é elaborada frente ao contexto da possibilidade de sua afirmação ou negação (KOßLER, 2012, p. 20). Então, se a dimensão normativa que está na base da teleologia ético-soteriológica está ligada à negação da vontade, a dimensão normativa que sustenta a teleologia funcional, ao contrário, está ligada à sua afirmação. Dentro desse contexto, a expressão conceitual escolhida por Schopenhauer para falar de seu princípio metafísico não é Wille zum Tod, ou Wille zur Selbsterkenntnis, ou Wille zum Nichts (em que pese a crítica nietzscheana, inteiramente justificada do ponto de vista da doutrina da redenção), mas sim Wille zum Leben.

diferente e agora encontrará o mundo em harmonia, senão com seus desejos, ao menos com sua intelecção. Os infortúnios de todo tipo e intensidade, embora lhe doam, não mais o surpreenderão; pois compreendeu claramente que dor e aflição trabalham precisamente em vista do verdadeiro fim da vida, a renúncia da vontade". Na sequência dessa passagem, Schopenhauer sugere que podemos reconhecer no fato de que o sofrimento é a "verdadeira destinação" da existência humana até mesmo um "toque de intencionalidade" (MVR II, p. 757), o que conecta este texto diretamente ao texto dos Parerga.

${ }^{29}$ Silva (2017) distingue, de modo bastante perspicaz, três definições de vida em Schopenhauer: do ponto de vista existencial, a vida é sofrimento; do ponto de vista metafísico (definição pela essência), a vida é vontade - ou "vontade de vida"; do ponto de vista científico, a vida equivale ao orgânico. 
III

Do tratamento da relação entre a estrutura da fórmula Wille zum Leben e a metáfora do espelho, passemos agora à discussão da possibilidade de uma consideração universal do princípio vital expresso nessa fórmula a partir de suas manifestações no mundo. Uma tal discussão nos permitirá, assim o espero, realizar duas tarefas: por um lado, compreender quais posições precisaremos assumir frente à metafísica da natureza de Schopenhauer para que estejamos justificados a reconhecer nela um tipo de vitalismo; por outro, distinguir três sentidos e três graus de abrangência possíveis desse suposto vitalismo, destacando algumas passagens da obra do autor que dão suporte para essa distinção. Nosso estudo como um todo tenderá à conclusão de que as teses defendidas nessas passagens não são unívocas, e a possibilidade de conciliar as diversas posições nelas apresentadas constitui um problema de difícil solução, que não pretendo resolver.

Comecemos por apresentar, de modo prévio e esquemático, os três sentidos e graus de abrangência que acredito podermos identificar quando falamos de vitalismo. Num sentido mais tradicional e relativamente simples, uma posição pode ser considerada vitalista na medida em que defende a autonomia das leis que regem os fenômenos da vida em relação às leis do restante da natureza, ou seja, na medida em que pensa a vida e o organismo como determinados por um princípio específico (normalmente chamado de "força vital") irredutível à causalidade física e, portanto, irredutível aos modelos de explicação químico e mecânico. Tradicionalmente, essa especificidade dos fenômenos vitais é caracterizada em termos teleológicos e holísticos. Isso significa, por um lado, que cada totalidade vital e orgânica deve ser pensada como atravessada por um tipo de intencionalidade ou causalidade final e, por outro, que a organização das partes dessa totalidade não pode ser pensada como mero agregado, em que as partes, tomadas individualmente, determinam a formação do todo, mas deve, antes, ser entendida como uma unidade em que o princípio do todo antecede e determina a organização das partes. O núcleo dessa posição se encontra muito bem especificado na segunda parte da terceira Crítica de Kant, está claramente presente na fisiologia de um Blumenbach (com seu conceito de Bildungstrieb), ${ }^{30}$ e suas linhas gerais são apresentadas por Hans Driesch, na introdução ao seu livro: Geschichte des Vitalismus (1922), como fio condutor para a análise histórica realizada por ele das posições vitalistas desde os gregos até a modernidade.

Num sentido mais radical e que implica, ao mesmo tempo, na pretensão de uma abrangência maior do domínio daquele princípio vital, uma posição vitalista pode defender não apenas a tese de que este princípio é irredutível às leis físicas e químicas, mas, ainda, que seu domínio não está restrito aos fenômenos orgânicos, podendo ser progressivamente expandido, de modo a desempenhar um papel ativo em toda atividade da natureza, inclusive no âmbito dos fenômenos inorgânicos. Nesse sentido, a força vital seria uma espécie de força constitutiva de toda causalidade natural, atravessando de modo variado e múltiplo a totalidade dos fenômenos, como elemento impulsionador de todo movimento rumo à realização de uma finalidade individual. Na perspectiva de uma tal posição, é

\footnotetext{
${ }^{30}$ Sobre isso, cf. por exemplo LENOIR, 1981, p. 136ss., e LARSON, 1979, p. 235ss.; sobre a relação entre Schopenhauer e Blumenbach, cf. SEGALA, 2013, e PRADO, 2017. Voltaremos rapidamente a isso na sequência.
} 
possível (mas não necessário) defender não apenas a irredutibilidade da força vital a outras forças naturais supostamente mais elementares (como as forças de atração e repulsão, por exemplo, gravidade e impenetrabilidade), mas, em certo sentido, a redutibilidade de todas as forças naturais a determinações de forças vitais, na medida em que é a força vital, enquanto dotada de uma causalidade final, que carrega em si o princípio de todo movente. Aqui, a força vital agiria a partir de dentro de cada ente natural, como algo imanente ao seu processo de formação. Essa é a leitura que Driesch faz, por exemplo, de Aristóteles, a partir de seu conceito de enteléquia. ${ }^{31}$

Num terceiro sentido, ainda mais inflacionado do ponto de vista metafísico, uma posição vitalista pode defender o caráter transcendente da vida, como uma espécie de fundamento primeiro da totalidade do ser. A força vital seria, nesse caso, não apenas um princípio movente que agiria individualmente a partir de dentro de cada ente no sentido da realização de sua finalidade, mas um princípio cósmico supra-individual que se desdobraria temporalmente na totalidade do mundo. É claro que, também nessa perspectiva, todas as forças da natureza são reconduzidas à força vital, mas não mais como um elemento interno à estrutura ontológica dos entes tomados individualmente, a partir do qual eles adquirem sua forma específica, mas como um princípio produtivo uno e originário, que antecede logicamente e determina ontologicamente a própria forma individual de cada ente. Assim, a finalidade que se tem em vista aqui não é mais compreendida a partir da forma específica de cada ente, mas como uma finalidade cósmica ou global, que abrange a unidade inteligível de toda a natureza, de modo que esta passa a ser vista como um imenso organismo, e sua vida como uma espécie de vida absoluta e infinita. Tal posição pode ser associada à filosofia da natureza de Schelling, por exemplo. ${ }^{32}$

Chamemos a primeira posição de vitalismo moderado, a segunda de vitalismo radical ou panvitalismo, e a terceira de vitalismo metafísico. ${ }^{33}$ A partir

${ }^{31}$ Cf. DRIESCH, 1922, p. 16: "Não podemos esquecer que Aristóteles é, por um lado, um 'dualista', na medida em que, para ele, a oposição conceitual entre forma e matéria (Stoff) é uma oposição originária; por outro lado, porém, quanto à realidade, ele não reconhece uma 'matéria' sem 'forma'. Ele é, portanto, 'vitalista' também no que diz respeito ao inorgânico, de modo que, em última instância, a única grande lacuna na realidade empírica é, para ele, aquela entre o espírito (nous) e todas as outras coisas", e não aquela entre orgânico e inorgânico ("vivo" e "não vivo"). Na medida em que Aristóteles entende a forma (Form), em oposição à pura matéria (Stoff), como um princípio formativo teleologicamente ativo, ele a veria então como um princípio vital. Mas como ela está presente também no reino inorgânico, como determinação formal de toda matéria existente, então este princípio vital se estenderia para a totalidade da natureza enquanto realidade ativa (enteléquia). Nesse sentido, o vitalismo de Aristóteles não poderia admitir um movimento puramente mecânico nem mesmo na esfera do inorgânico. No século XIX, uma posição semelhante é defendida por Adolf Trendelenburg, que pretende reabilitar a teleologia aristotélica no âmbito de uma reflexão especulativa, não nos moldes do idealismo hegeliano, criticado por ele, mas a partir das mais recentes pesquisas em embriologia e na fisiologia dos sentidos. Trendelenburg entende o movimento não apenas como mudança de lugar, mas como a realização de uma potencialidade, o vir-a-ser da forma de um ente. Trata-se, assim, da atividade pela qual algo realiza seu fim. Enquanto tal, o movimento seria a atividade criativa de um princípio vital, uma realidade constitutiva da dinâmica de todo movimento (BEISER, 2013, p. 38s.).

32 Sobre isso, cf. por exemplo REILL, 2005, p. 214s., BEISER, 2013, p. 36s. e, no que diz respeito aos aspectos do vitalismo de Schelling que teriam repercutido profundamente em Schopenhauer, cf. BARBOZA, 2005, p. 73ss.

33 Não que a segunda ou mesmo a primeira posição não possam ser consideradas metafísicas, a 
dessa distinção, iniciemos agora uma análise das posições defendidas por Schopenhauer em sua metafísica da natureza, tendo em vista determinar em que medida elas podem ou não ser consideradas vitalistas e, em caso afirmativo, qual seria o sentido mais adequado para se compreender esse vitalismo. ${ }^{34}$

\section{IV}

Num capítulo dedicado especificamente ao tema da vida em Schopenhauer, Lefranc (2007, p. 110) argumenta que "não seria cabível falar de um vitalismo de Schopenhauer". Essa afirmação se justificaria pelo fato de que, apesar de o filósofo defender "a irredutibilidade da força vital a uma explicação puramente mecanicista", não podemos esquecer que, para ele, todas as outras forças naturais se subtraem igualmente a qualquer tentativa de explicação causal ou redutiva. Isso significa que não podemos reduzir as forças químicas a forças físicas, nem as forças físicas a mecânicas, por exemplo. Cada força natural originária corresponde a uma forma específica ${ }^{35}$, a uma ideia, não mais explanável segundo o princípio de razão e, portanto, não mais redutível a um explanans logicamente anterior: "sempre restará, como resíduo insolúvel, um conteúdo do fenômeno que não pode ser remetido à sua forma; sempre restará, portanto, algo não mais explanável por outra coisa e em conformidade com o princípio de razão" (MVR I, p. 184). Disso se conclui que "é tão inexplicável que uma pedra caia em direção à terra quanto o é que um animal se movimente" (MVR I, p. 185).

É nesse contexto que Schopenhauer sugere a existência de uma lacuna na tese kantiana de que não estamos autorizados a esperar por um "Newton do ramo de relva" (MVR I, p. 206), pois "jamais chegaremos a explicar a índole dos corpos orgânicos a partir de simples causas mecânicas" (CK, p. 661). A explicação do sentido dessa lacuna merece uma citação integral:

Com efeito, ele nega essa possibilidade de explicação apenas com vistas à conformidade a fins e à aparente intencionalidade dos corpos orgânicos. Nós, entretanto, achamos que, também onde estes não se encontram, os fundamentos explicativos não podem ser transferidos de um domínio da natureza para outro; antes, tão logo entramos em um novo domínio, eles nos abandonam e, no lugar deles, entram em cena novas leis fundamentais, cuja explanação não se pode de modo algum esperar daquelas pertencentes ao domínio anterior. Assim, no domínio do mecânico propriamente dito regem as leis da gravidade, da coesão, da rigidez, fluidez, elasticidade, as quais em si [...] existem como exteriorizações de forças não mais explicáveis, mas constituem elas mesmas os princípios de toda ulterior explicação, que consiste meramente na remissão a elas. Caso deixemos esse domínio e

depender do modo como compreendemos esse conceito. Essa denominação servirá aqui apenas para distinguir as posições e não depende essencialmente de nenhum compromisso prévio com uma definição de metafísica. Ela tem como horizonte, porém, o sentido que Schopenhauer atribui ao termo ao associá-lo à especulação sobre a coisa em si enquanto vontade.

34 No que se segue dessa primeira parte do estudo, me limitarei a discutir as posições de Schopenhauer que o vinculam ao primeiro sentido do vitalismo. A segunda parte se dedicará à continuação dessa análise, que buscará investigar se e em que medida o filósofo pode ser vinculado ao segundo e ao terceiro sentidos.

${ }^{35}$ Schopenhauer emprega aqui o conceito de forma substantialis (cf. MVR I, p. 185 e p. 206). 
passemos aos fenômenos do quimismo, da eletricidade, do magnetismo, da cristalização, aqueles princípios não são mais utilizáveis, sim, aquelas leis não valem mais. Essas forças são dominadas por outras, e os fenômenos entram em contradição direta com elas, segundo novas leis fundamentais, que, precisamente como as primeiras, são originárias e inexplicáveis, isto é, não mais remissíveis a leis mais universais. Assim, por exemplo, jamais conseguiremos explicar, segundo as leis do mecanismo propriamente dito, a solução de um sal na água, para não mencionar os fenômenos mais complicados da química (CK, p. 661s.).

É importante que tenhamos clareza com relação ao que é dito aqui: a lacuna apontada por Schopenhauer diz respeito ao fato de Kant ter circunscrito a impossibilidade de uma explicação mecânica apenas aos fenômenos orgânicos, isto é, basicamente, à força vital, ao passo que ele próprio buscará expandir esta irredutibilidade à totalidade da natureza, ou seja, à tessitura de todas as forças naturais originárias. Se entendermos essa irredutibilidade como uma via de mão dupla, devemos pensar que, assim como não podemos reduzir a força vital a forças supostamente mais universais e elementares, tampouco estaríamos autorizados a reduzir outras forças à força vital.

Mas notemos que, segundo a distinção que fizemos acima entre três sentidos e níveis de abrangência do vitalismo, a defesa de uma força vital irredutível já configura, por si mesma, uma posição vitalista (moderada ou tradicional). Para Lefranc (2007, p. 110), na medida em que defende a irredutibilidade da força vital ao mecanismo, Schopenhauer poderia ser considerado um vitalista num sentido meramente negativo. Em que pese o caráter moderado e metafisicamente deflacionado dessa forma de vitalismo, não me parece inteiramente adequado qualificá-la num sentido meramente negativo, já que ela corresponde ao núcleo próprio do vitalismo tradicional, tal como o compreende Driesch (1992, p. 1ss.), por exemplo, que atribui a Schopenhauer uma tal posição.

No parágrafo 24 do primeiro tomo do Mundo, encontramos uma formulação clara dessa posição na forma de uma crítica ao atomismo e ao materialismo do século XIX:

Naturalmente, em todos os tempos uma etiologia ignara de seu fim empenhou-se em reduzir toda vida orgânica ao quimismo ou à eletricidade; e todo quimismo, isto é, toda qualidade ao mecanismo (efeito através da figura dos átomos) [...] Por fim, totalmente nesses moldes é até mesmo o tosco materialismo agora requentado no meio do século XIX, e que, por ignorância, tomou a si mesmo como original: em primeiro lugar, sob a estúpida negação da força vital, procurando explanar os fenômenos da vida a partir de forças físicas e químicas e estas, por seu turno, a partir do fazer-efeito mecânico da matéria, posição, figura e movimento de átomos oníricos. (MVR I, p. 182s. Cf. ainda MVR I, p. 205s.).

As duras críticas de Schopenhauer aos materialistas e à sua obsessão por uma redução de todo fenômeno a "choque e contra-choque", que vêm acompanhadas de uma defesa diligente da força vital como princípio irredutível, colocam nosso filósofo como representante de um movimento significativo na 
biologia da primeira metade do século XIX, na esteira e ao lado de figuras importantes como Blumenbach, Haller, Reil e Treviranus, todos estes personagens que figuram, com maior ou menor peso, nos bastidores da produção intelectual do autor de Sobre a vontade na natureza. ${ }^{36}$

Desses personagens, Blumenbach é muito provavelmente o mais relevante. Apesar da escassez de referências diretas ao ilustríssimo professor da Universidade de Göttingen na obra publicada de Schopenhauer, Blumenbach é certamente um dos pensadores que tiveram maior influência sobre o desenvolvimento de sua filosofia da natureza e de sua metafísica de um modo geral. O jovem filósofo foi ouvinte assíduo dos seminários de Blumenbach na Universidade Georgia Augusta, durante seus anos de formação em Göttingen, entre 1809 e 1811. ${ }^{37}$ De especial importância para o escopo de nosso trabalho é a concepção blumenbachiana do "impulso formativo" (nisus formativus ou Bildungstrieb), conceito ao qual Blumenbach pretende reconduzir uma série de processos vitais ligados à geração, nutrição, reprodução e regeneração do organismo, ou seja, à formação embrionária e à constituição e restauração da matéria orgânica, que não poderiam ser explicados pela mera causalidade mecânica. O conceito de Bildungstrieb teve um efeito profundo e duradouro sobre o pensamento biológico na virada do século XVIII para o século XIX, tendo desempenhado um papel fundamental na concepção kantiana da vida e na filosofia da natureza de Schelling, por exemplo ${ }^{38}$. Driesch (1922, p. 57) vê no escrito seminal de Blumenbach: Über den Bildungstrieb (Sobre o impulso formativo, 1781) "um verdadeiro sistema do vitalismo".

As reflexões de Schopenhauer sobre a vida, a fisiologia, a anatomia comparada e os diversos graus de relação e de oposição entre leis mecânicas e leis vitais, assim como sobre a relação entre ciência natural e metafísica, são certamente atravessadas pelas teorias de Blumenbach e trazem ressonâncias das lições ouvidas pelo jovem filósofo em Göttingen, mesmo quando mediadas pelas filosofias de Kant e Schelling e por teorias fisiológicas de outros autores que the serviram igualmente de inspiração ou como confirmação suplementar de sua doutrina. Digna de nota, nesse contexto, é a menção ao médico dinamarquês Joachim Dietrich Brandis, presente em Sobre a vontade na natureza - escrito que contém, já nas primeiras páginas do prefácio à segunda edição, uma crítica mordaz ao que ele chama de "materialismo grosseiro e estúpido", cujos representantes teriam sido conduzidos à "insensatez inacreditável" de negar até a mesmo a "força vital, rebaixando a natureza orgânica a um jogo aleatório de forças químicas" (VN, p. 24). Brandis é autor de um Ensaio sobre a força vital (Versuch über die Lebenskraft, 1795), referenciado por Schopenhauer no primeiro capítulo: "Fisiologia e patologia", com a indicação de que o ensaio teria sido recebido com especial louvor por Reil, outro pensador vitalista importante da virada do século XVIII para o XIX. O texto da primeira edição faz menção a dois artigos mais recentes de Brandis, um de 1833 e outro de $1834,{ }^{39}$ nos quais o autor teria instituído, "da forma mais expressiva e admirável, uma vontade inconsciente como a fonte primordial

${ }^{36}$ Cf. sobre isso MALTER, 1983b; SEGALA, 1994; SEGALA, 2013; PRADO, 2015.

${ }^{37}$ Cf. SEGALA, 2013, e PRADO, 2017.

38 Cf. REILL, 2005, p. 214s., e SEGALA, 2013, p. 37.

39 Erfahrungen über die Anwendung der Kälte in Krankheiten (Experiências sobre a aplicação do frio em doenças, 1833) e Nosologie und Therapie der Kachexien (Nosologia e terapia das caquexias, 1834). 
de todas as funções vitais", e derivado dela "todos os eventos no funcionamento do organismo, tanto no estado doente como no saudável", apresentando-a como o "primum mobile da vida" (VN, p. 53). Schopenhauer traz então uma série de citações do artigo de 1833 que confirmariam seu dogma central.

O que a segunda edição traz de novo com relação ao médico dinamarquês é menos elogioso: uma acusação de plágio! Entrementes, Schopenhauer parece ter chegado ao conhecimento de que a tese de Brandis de uma vontade inconsciente como fonte primordial de todas as funções vitais foi retirada de seu pensamento fundamental, sem qualquer referência que indicasse tal empréstimo, como exige a probidade literária (VN, p. 58). A mesma acusação é repetida no capítulo 20 do segundo tomo do Mundo: "Objetivação da vontade no organismo animal", texto no qual o conceito de "força vital" desempenha igualmente um papel muito importante. Ali, antes de denunciar mais uma vez o suposto plagiário, ele argumenta que a concepção em voga na patologia, segundo a qual "as doenças mesmas são um processo de cura da natureza", em que ela "ou consegue a vitória e atinge seus fins, ou sucumbe", só adquire racionalidade a partir do ponto de vista que reconhece a vontade na força vital, "que aqui entra em cena como vis naturae medicatrix [poder de cura da natureza]" (MVR II, p. 314s.).

Voltando ao primeiro capítulo de Sobre a vontade na natureza, Schopenhauer discute ainda, na sequência, o vitalismo animista de Georg Ernst Stahl, que, apesar de ter chegado muito perto da verdade, foi dela desviado por uma falsa concepção da alma, vendo-a como substrato racional de todos os processos vitais. Sob influência de uma tal ideia de alma, Stahl teria sido desencaminhado para a tese de que "seria essa alma simples e racional que teria construído o corpo para si, guiando e realizando todas as suas funções orgânicas internas" (VN, p. 65). Mas se essas funções são realizadas, como é sabido, de modo inteiramente inconsciente, como poderia a alma racional ser seu agente próprio? Schopenhauer coloca essa questão indiretamente, ao apresentar de modo problemático a tese stahliana de que, embora a cognição seja a determinação fundamental e a substância essencial da alma, esta deveria estar ativa nos processos orgânicos sem saber ou experimentar qualquer coisa daqueles processos. Ele então conclui: "haveria aí algo de absurdo, que tornava a doutrina totalmente insustentável" (VN, p. 65s.).

Ora, estamos aqui diante de um dos problemas seminais que motivaram a elaboração do conceito de "força vital" na literatura médica e antropológica da segunda metade do século XVIII e, mais ainda, diante daquele que é talvez o principal impasse a partir do qual se desenhará, na modernidade, uma noção de inconsciente de cunho vitalista. ${ }^{40} \mathrm{E}$ isso porque o conceito de força vital surge justamente para dar conta de uma série de processos orgânicos e movimentos involuntários do corpo, como o metabolismo, a digestão, os batimentos cardíacos, para os quais uma explicação puramente mecânica não parecia satisfatória, mas que não poderiam ser remetidos de modo consequente à atividade da alma, uma vez que ocorrem de forma inteiramente inconsciente. Assim, a força vital surge, de início, como uma espécie de terceiro princípio ou substância, ao lado da alma e do corpo material. Ela seria ainda responsável pela sensibilidade e pela irritabilidade, isto é, pela capacidade de perceber estímulos e de reagir a eles, assim

${ }^{40}$ Cf. GOLDMANN, 2011, p. 126s., e GÖDDE, 2009, p. 35ss. 
como pelos processos de constituição orgânica, na qualidade de força vital plástica (GOLDMANN, 2011).

Esses são justamente os aspectos definidores da força vital segundo Haller, autor referido na sequência do texto schopenhaueriano como aquele cuja "doutrina da sensibilidade e da irritabilidade" teria suplantado o vitalismo animista de Stahl (VN, p. 66). Movimentos involuntários, como os batimentos cardíacos e os movimentos das entranhas, por exemplo, eram agora atribuídos à irritabilidade. Mas apesar de sua superioridade com relação à teoria de Stahl, a doutrina de Haller se depara ainda com basicamente dois problemas: em primeiro lugar, encontra seu limite explicativo em duas qualidades ocultas (sensibilidade e irritabilidade), não mais explicáveis; em segundo lugar, mantém ainda a alma racional "inabalada em suas honras e louvores, como um hóspede estranho na casa do corpo, instalado no sótão" (VN, p. 66).

O voluntarismo schopenhaueriano pretende superar esses problemas com base em duas teses centrais: a tese de que toda atividade do organismo deve ser reconduzida à atividade da vontade que constitui sua essência; e a tese de que essa vontade é anterior e independente da cognição. Ao contrário das assim chamadas qualidades ocultas, a vontade nos é conhecida de modo imediato e completo $^{41}$ : e ao contrário do que nos diz a maior parte dos filósofos da tradição, a cognição, isto é, aquilo que os filósofos tradicionalmente associam à atividade própria da alma e que determinaria a vontade, não passa de mera função orgânica (cerebral), sendo inteiramente dependente da vontade: um produto desta última para fins de conservação do organismo. Temos aqui um esquema trial: 1) vontade (coisa em si, absolutamente originária); 2) organismo (mera visibilidade ou objetivação da vontade); 3) cognição (mera função de uma parte do organismo, o cérebro). Portanto, o "princípio vital", para Schopenhauer, não é a alma, mas sim aquilo que ele chama de "radical da alma": a vontade (VN, p. 66), e esta é essencialmente inconsciente. Nos Parerga, essa tese é apresentada nos seguintes termos: "A força vital é realmente idêntica à vontade; de modo que aquilo que se apresenta à autoconsciência como vontade, é, na vida orgânica inconsciente, aquele primum mobile da mesma, o qual foi muito adequadamente designado como força vital" (PP II, p. 175).

Voltaremos a falar sobre essa identidade entre força vital e vontade logo à frente. Antes disso, porém, cabe discutirmos ainda um pouco mais profundamente o modo como Schopenhauer caracteriza essa força vital no texto dos Parerga acima citado, que leva o título: "Sobre a filosofia e a ciência da natureza". Os parágrafos mais importantes, nesse sentido, são os $\$ \$ 93,94$ e 95. Ali, Schopenhauer define a vida como "a condição de um corpo na qual este, sob a mudança constante da matéria (Materie) mantém sempre a forma (substancial) que lhe é essencial" (PP II, p. 173). Trata-se da mesma caracterização que encontramos em outros momentos de sua obra, nos quais a distinção entre orgânico e inorgânico é apresentada justamente em termos da relação entre forma e matéria. Enquanto nos corpos inorgânicos o que determina sua identidade é a permanência da matéria

${ }^{41}$ Cf. por exemplo MVR I, p. 171: "Se, portanto, remetemos o conceito de força ao de vontade, em realidade remetemos algo desconhecido a algo infinitamente mais bem conhecido, àquilo que unicamente nos é conhecido de maneira imediata e completa e que amplia de maneira enorme nosso conhecimento". 
sob a mudança da forma, nos corpos orgânicos a identidade é pensada, alheia à mudança na matéria, como a permanência da forma, enquanto forma substancial, que não é outra coisa senão a ideia do organismo. ${ }^{42}$ Mas o que faz com que essa forma seja mantida, guiando e orientando as forças naturais em atividade na mudança da matéria, é justamente a força vital: "no organismo, estão em atividade forças físicas e químicas: mas o que as guia e as mantém coesas, de modo que, daí, um organismo conforme a fins se origine e se conserve, - é a força vital" (PP II, p. 174). É ela que domina e modifica o efeito das forças naturais em atividade no organismo, visando sempre a conservação da forma e resistindo ininterruptamente à tendência à desagregação advinda da luta das outras forças pelo domínio da matéria. ${ }^{43}$

Note-se que Schopenhauer não nega a presença pervasiva de forças químicas e físicas nos processos orgânicos. O que faz com que o fisicalismo não dê conta de explicar a legalidade própria desses processos é sua incapacidade de reconhecer que, no organismo, essas forças estão subordinadas à direção da força vital, cuja atividade só pode ser compreendida segundo um tipo de causalidade distinta da causa eficiente: necessitamos aqui do recurso à causa final. Sem a assunção de uma força específica, a cuja essência pertence um agir conforme a fins, do mesmo modo que à essência da gravidade pertence a capacidade de aproximar os corpos; sem a assunção de uma força específica por trás da complexa dinâmica autorreguladora do organismo, e que se manifesta nele assim como a gravidade se manifesta nos fenômenos de queda e da gravitação, a vida seria uma "aparência falsa, uma ilusão enganadora", e todo ente seria "um mero autômato, isto é, um jogo de forças mecânicas, físicas e químicas” (PP II, p. 173s.). Ao reconhecer, no organismo, a atividade pervasiva dessas forças, subordinando-as, contudo, à direção da força vital, Schopenhauer está mais próximo de uma posição que podemos chamar de "neo-vitalista". ${ }^{44}$

\footnotetext{
${ }^{42}$ Cf. por exemplo MVR II, p. 356s.: "Nos corpos inorgânicos, o essencial e permanente, logo, aquilo em que se baseia a sua identidade e integridade, é o estofo (Stoff), a matéria (Materie); por outro lado, o inessencial e mutável é a forma. Com os corpos orgânicos ocorre exatamente o contrário: pois sua vida, isto é, sua existência como algo orgânico, consiste precisamente na mudança contínua do estofo em meio à permanência da forma". Sobre isso, cf. ainda Soria 2012, p. 199s.

${ }^{43}$ Cf. por exemplo MVR I, p. 210ss.; sobre isso, cf. ainda DECHER, 1984, p. 60ss. Moreira (2011, p. 52) apresenta de modo bastante detalhado a argumentação de Schopenhauer em torno da luta entre as ideias pelo domínio da matéria e confere um grande peso a esta tese, no intuito de mostrar que, segundo Schopenhauer, não estamos autorizados a ver no inorgânico qualquer tendência a ser tornar um ser vivo. Voltarei a esse ponto na segunda parte deste estudo e tentarei apontar um pequeno problema no argumento de Moreira, na medida em que peca ao não fazer uma distinção entre dois pontos de vista: o ponto de vista dos entes tomados individualmente e o da natureza em sua totalidade. Em resumo, meu argumento é o seguinte: se não é inteiramente adequado dizer que um ser inorgânico quer se tornar um ser orgânico (vivo), como argumenta Moreira, essa inadequação só pode ser afirmada do ponto de vista de cada ente tomado individualmente, isto é, de cada micrototalidade individuada no mundo da representação. Do ponto de vista da totalidade da natureza e de sua unidade inteligível, porém, me parece sim fazer sentido a afirmação de que o reino inorgânico quer, se não se tornar propriamente vivo, no sentido estrito do termo, ao menos produzir a vida a partir de si mesmo. É isso que está por trás da ideia de que todos os reinos "se complementam para a objetivação plena da vontade” (MVR I, p. 219), a qual, por sua vez, é o que fundamenta a tese de uma finalidade externa na natureza (cf. em especial MVR I, p. 226).

44 Cf. o verbete "Vitalismus" do Wörterbuch der philosophischen Begriffe, de Rudolf Eisler, disponível em < https://www.textlog.de/5377.html>. Essa é a posição assumida por Hans Driesch, e que já se encontra presente em Blumenbach, na medida em que ele compreende que toda matéria
} 
Como a força vital está conectada essencialmente à manutenção da forma do organismo, uma vez que ela tenha abandonado um corpo, e a estrutura formal deste último tenha sucumbido ao domínio das forças do reino inorgânico, ela não pode, diferentemente de outras forças, como o magnetismo ou a eletricidade, voltar a dominá-lo segundo aquele mesmo princípio formal que lhe era anteriormente inerente. Mas ela pode dar início a um novo processo de produção de formas a partir da origem, "ab ovo" (PP II, p. 175). Tendo isso em vista, gostaria de destacar aqui três pontos, antecipando alguns temas que abordarei mais detalhadamente na segunda parte deste estudo: em primeiro lugar, a tese schopenhaueriana de que a origem das formas e, consequentemente, de qualquer forma vital ou orgânica (o que inclui as espécies animais em geral), é a matéria tese formulada no importante capítulo 24 do segundo tomo do Mundo (MVR II, p. $373)^{45}$; em segundo lugar, a concepção segundo a qual a vida se origina, do ponto de vista de sua produção material, por generatio aequivoca ou geração espontânea (Urzeugung) (VN, p. 109; MVR II, p. 373s.; PP II, p. 163); ${ }^{46}$ em terceiro lugar, a enigmática afirmação de que a recusa da generatio aequivoca, por parte de alguns estudiosos da biologia, abriu as portas para a negação da força vital e está ligada a essa negação (MVR II, p. 375). Menciono estes pontos aqui apenas para indicar sua importância para o presente tema, na medida em que o texto dos Parerga sob discussão faz referência ao problema da vitalização ou revitalização $a b$ ovo da matéria inorgânica pela força vital. Antes de nos debruçarmos mais detidamente sobre a relação entre matéria e força vital (o que faremos, como indicado, na segunda parte deste estudo), devemos ainda retomar rapidamente a relação apresentada entre força vital e vontade e a questão de sua irredutibilidade.

Como vimos, Schopenhauer é um detrator inveterado da estupidez dos materialistas que pretendem negar a existência da força vital. O texto dos Parerga que nos ocupa no momento não decepciona nesse sentido: "A polêmica, que se torna moda nos dias de hoje, contra a assunção de uma força vital merece, apesar de seus gestos nobres, não tanto ser chamada de falsa quanto de estúpida". E ele então arremata: "Pois quem nega a força vital nega, no fundo, sua própria existência (Dasein), e pode portanto vangloriar-se de ter alcançado o cume da absurdidade" (PP II, p. 173).

Mas o que é, em última instância, essa força vital? A resposta nos é dada na sequência do texto: "Em si, aquela força vital é a vontade" (PP II, p. 174). A afirmação que citamos anteriormente, segundo a qual a força vital é idêntica à

exibe os efeitos de forças químicas e físicas, inclusive a matéria viva. Larson (1979, p. 236) apresenta a posição de Blumenbach nos seguintes termos: no organismo, as afinidades químicas seriam responsáveis pelas mudanças que ocorrem no processo respiratório e, igualmente, os raios de luz que chegam ao olho num certo ângulo passam por ele por meio de forças físicas, sofrendo o efeito da densidade e da geometria da córnea, e sendo refratados em direção ao eixo visual. Contudo, encontramos em todos os corpos organizados uma outra ordem de efeitos não redutíveis meramente às forças físicas e químicas. Na verdade, esses efeitos demonstram clara superioridade com relação às forças da assim chamada matéria morta. Durante a vida, eles se opõem às forças químicas que induzem a putrefação e, do mesmo modo, superam a força da gravidade a tal ponto que um músculo morto se romperia sob o mesmo peso que, quando vivo, poderia facilmente levantar.

45 Sobre isso, cf. FRAUENSTÄDT, 1876, p. 193. Sobre o conceito de matéria em Schopenhauer, cf. o exaustivo estudo monográfico de Brandão (2008).

${ }^{46}$ Sobre isso, cf. ainda MOREIRA, 2011, p. 57s., e FRANÇOIS, 2011, p. 40s. 
vontade, é feita logo à frente (PP II, p. 175). Diante dessa afirmação, talvez pudéssemos colocar a pergunta em que consiste essa identidade entre força vital e vontade. Trata-se aqui de uma identidade conceitual ou de uma identidade essencial, isto é, de uma identidade semântica ou do ponto de vista metafísico? O texto parece não deixar dúvidas de que se trata do segundo caso, de uma identidade do ponto de vista metafísico, já que a vontade é referida àquilo que a força vital é em si. Com efeito, se é verdade que a força vital é idêntica à vontade, "todas as demais forças naturais também o são; embora isto esteja menos evidente" (MVR II, p. 356). Lefranc (2007, p. 103s.) faz questão de sublinhar este ponto, no intuito de recusar qualquer leitura vitalista que pretenda conceder à força vital algum tipo de prerrogativa metafísica.

De todo modo, não deixa de ser interessante atentar para uma curiosidade na sequência do texto: Schopenhauer formula aqui uma versão do argumento da analogia na qual o domínio fonte é a própria força vital, e o domínio alvo o restante das forças. É apenas por analogia com a força vital presente em nosso próprio organismo que inferimos que também as outras forças naturais são, no fundo, idênticas à vontade (PP II, p. 175). Digna de nota é ainda a designação dessa força vital como "Urkraft" (força originária ou primordial), designação da qual Schopenhauer não parece se valer para a caracterização de nenhuma outra força natural, ficando o termo reservado apenas à própria vontade e à força vital. ${ }^{47}$

Não quero, com isso, afirmar que se trate efetivamente de uma identidade conceitual entre força vital e vontade, apenas indicar que há certas ambiguidades no texto que podem nos conduzir, se não diretamente à elevação da força vital a uma categoria metafísica superior e mais abrangente com relação às outras forças, ao menos à concessão de um claro privilégio a esta força originária no que diz respeito à sua relação com a vontade. Ruy de Carvalho Rodrigues argumenta nessa direção, ao pensar a relação desta força com a matéria:

Talvez se possa pensar que as forças naturais (Naturkräften) espelham uma força vital (Lebenskraft) una (eine), uma força originária (Urkraft) enquanto princípio metafísico (metaphysisch), isto é, coisa em si (Ding an sich)/Vontade (Wille). E que esta, aparecendo como forças naturais, manifesta-se na matéria originária (Urmaterie), a qual funciona como seu suporte. (RODRIGUES, 2011, p. 273).

O comentário de Rodrigues é oportuno, pois ilustra bem a tese geral que serviu de fio condutor de nossa discussão até o momento, ao mesmo tempo em que abre portas para avançarmos rumo ao segundo e ao terceiro sentidos que identificamos ser possível atribuir a uma posição vitalista: o vitalismo radical ou panvitalismo, e o vitalismo metafísico. A partir de tudo que foi dito até aqui, creio poder afirmar com algum grau de certeza que Schopenhauer é um vitalista ao menos no primeiro sentido, isto é, um vitalista moderado, e está muito próximo do modo como Eisler e Driesch caracterizam o neo-vitalismo. Caberia investigar agora se ele pode ser considerado um vitalista nos dois outros sentidos e, para isso, é fundamental que reflitamos sobre a relação apontada por Rodrigues entre força vital e matéria. Mas isso será objeto da segunda parte deste estudo. ${ }^{48}$

${ }^{47}$ Cf. por exemplo MVR II, p. 353; MVR II, p. 388; MVR II, p. 570; PP II, p. 299.

${ }^{48}$ Parte do que eu tenho a dizer sobre isso é inspirado no já mencionado estudo de Brandão: $A$ 


\section{REFERÊNCIAS BIBLIOGRÁFICAS}

ANTONIASSI, Ednilson Bernardo. A noção de palingenesia na filosofia de Schopenhauer: uma contribuição para os debates sobre o processo de negação da vontade. In: DEBONA, Vilmar; DECOCK, Diana Chao (Eds.). Schopenhauer. $A$ filosofia e o filosofar [recurso eletrônico]. Porto Alegre: Editora Fi, 2018. p. 87-102.

ATWELL, John. Schopenhauer on the character of the world: the metaphysics of Will. Berkeley: University of California Press, 1995.

ATZERT, Stephan. Zwei Aufsätze über Leben und Tod: Sigmund Freuds Jenseits des Lustprinzips und Arthur Schopenhauers Transscendente Spekulation über die anscheinende Absichtlichkeit im Schicksal des Einzelnen. Schopenhauer Jahrbuch, v. 86, p. 179-194, 2005.

BARBOZA, Jair. Infinitude subjetiva e estética. Natureza e arte em Schelling e Schopenhauer. São Paulo: Ed. UNESP, 2005.

BEISER, Frederick. Late German Idealism Trendelenburg and Lotze. Oxford: Oxford University Press, 2013.

BRANDÃO, Eduardo. A concepção de matéria na obra de Schopenhauer. São Paulo: Humanitas, 2008.

CACCIOLA, Maria Lucia. A Morte, Musa da Filosofia. Cadernos de Filosofia Alemã, n. 9, p. 91-107, 2007.

A filosofia da natureza em Schopenhauer. In: BULHÕES, Fernanda; LEITE, Cinara N.; SILVA, Markus F. (Eds.). Natureza e metafísica: Atas do IV Colóquio Internacional de Metafísica. Natal: EDUFRN, 2015. p. 31-42.

DECHER, Friedhelm. Wille zum Leben - Wille zur Macht. Eine Untersuchung zu Schopenhauer und Nietzsche. Würzburg: Königshausen und Neumann; Amsterdam: Rodopi, 1984.

DRIESCH, Hans. Geschichte des Vitalismus. Zweite verbesserte und erweiterte Auflage des ersten Hauptteils des Werkes: "Der Vitalismus als Geschichte und als Lehre”. Leipzig: Verlag von Johann Ambrosius Barth, 1922.

FRANÇOIS, Arnaud. Existe uma filosofia schopenhaueriana da vida? A questão da espécie como Ideia. Revista Voluntas: Estudos sobre Schopenhauer, v. 2, n. 2, p. 31-43, 2011.

FRAUENSTÄDT, Julius. Neue Briefe über die Schopenhauer'sche Philosophie. Leipzig: F. Brockhaus, 1876.

GERMER, Guilherme Marconi. A concepção de morte em Schopenhauer. In: DEBONA, Vilmar; DECOCK, Diana Chao (Eds.). Schopenhauer. A filosofia e o filosofar [recurso eletrônico]. Porto Alegre: Editora Fi, 2018. p. 69-86.

concepção de matéria na obra de Schopenhauer (2008), em especial nos capítulos 1.4, 2.3 e 3.1, nos quais Brandão recupera o referencial aristotélico da teoria schopenhaueriana da matéria e sua proximidade com Leibniz, destacando a emergência da noção de uma "atividade original" da matéria e a consequente ressignificação do conceito de vida que resulta daí (cf. BRANDÃO 2008, p. 191ss.). 
GÖDDE, Günter. Traditionslinien des „Unbewußten“. Schopenhauer - Nietzsche Freud. Gießen: Psychosozial-Verlag, 2009.

GOLDMANN, Stefan. Von der "Lebenskraft" zum "Unbewussten" - Stationen eines Konzeptwandels der Anthropologie. In: BUCHHOLZ, Michael e GÖDDE, Günther (Eds.). Macht und Dynamik des Unbewussten. Auseinandersetzungen in Philosophie, Medizin und Psychoanalyse. 2. Auflage. Gießen: Psychosozial-Verlag, 2011. p. 125-152.

KANT, Immanuel. Crítica da faculdade de julgar. Trad. Fernando Costa Mattos. Petrópolis: Editora Vozes, 2016.

KEUTEL, Otto. Über die Zweckmäßigkeit in der Natur bei Schopenhauer. Leipzig: Bruno Zechel, 1897.

KOßLER, Matthias. "A vida é apenas um espelho" - o conceito crítico de vida de Schopenhauer. Ethic@, v. 11, n. 2, p. 17-30, jul. 2012.

LARSON, James. Vital Forces: Regulative Principles or Constitutive Agents? A Strategy in German Physiology, 1786-1802. Isis, v. 70, n. 2, p. 235-249, jun. 1979.

LEFRANC, Jean. Compreender Schopenhauer. 3. ed. Trad. Ephraim Ferreira Alves. Petrópoles: Vozes, 2007.

LENOIR, Timothy. The Göttingen School and the Development of Transcendental Naturphilosophie in the Romantic Era. Studies in the History of Biology, v. 5, p. 111-205, 1981.

MALTER, Rudolf. Schopenhauers Transzendentalismus. Midwest Studies in Philosophy, v. 8, n. 1, p. 433-455, 1983 a.

- Schopenhauer und die Biologie: Metaphysik der Lebenskraft auf empirischer Grundlage. In: Berichte zur Wissenschaftsgeschichte, Akademische Verlagsgesellschaft, 1983b.

MATTIOLI, William. O paradoxo das causas finais: Schopenhauer leitor da "Crítica do juízo teleológico". Revista de Filosofia Aurora, v. 30, n. 49, p. 205-235, jan./abr. 2018.

MOREIRA, Fernando de Sá. Sobre a relação entre vida e vontade na metafísica da natureza de Schopenhauer. Revista Voluntas: Estudos sobre Schopenhauer, v. 2, n. 2, p. 44-62, 2011.

Do caráter do mundo ao homem enquanto caráter. Uma investigação das doutrinas de identidade pessoal em Schopenhauer e Nietzsche. Tese de doutorado. Curitiba: Pontifícia Universidade Católica do Paraná, 2015.

PHILONENKO, Alexis. Schopenhauer. Une philosophie de la tragédie. Paris: Librairie Philosophique, 1980.

PRADO, Jorge Luis Palicer do. Metafísica e ciência: A vontade e a analogia em Schopenhauer. Revista Voluntas: Estudos sobre Schopenhauer, v. 6, n. 1, p. 44-84, 2015. 
Schopenhauer e Blumenbach: Vontade, impulso formativo e a conexão entre metafísica e ciência. In: CORREIA, Adriano; DEBONA, Vilmar; TASSINARI, Ricardo. (Orgs.). Hegel e Schopenhauer. Coleção XVII Encontro ANPOF. São Paulo: ANPOF, 2017. p. 220-232.

REILL, Peter Hanns. Vitalizing Nature in the Enlightenment. Berkeley/Los Angeles/London: University of California Press, 2005.

ROCHA, Leandro José; SILVA, Luan Corrêa da; BAZZANELLA, Sandro Luiz. A vida em Kant, em Schopenhauer e em Nietzsche. Revista Lampejo, v. 6, n. 2, p. 07-34, 2017.

RODRIGUES, Ruy de Carvalho. Schopenhauer: uma filosofia do limite. Tese de doutorado. São Paulo: Pontifícia Universidade Católica de São Paulo, 2011.

SCHOPENHAUER, Arthur. Sämtliche Werke. Hrsg. v. Paul Deussen. München: Piper Verlag, 1911-1926. (Werke auf CD-ROM: Schopenhauer im Kontext).

. O mundo como vontade e como representação. Trad. Jair Barboza. São Paulo: Editora Unesp, 2005. Tomo I.

Sobre a vontade na natureza. Trad. Gabriel Valladão Silva. Porto Alegre: L\&PM, 2013.

O mundo como vontade e como representação. Trad. Jair Barboza. São Paulo: Editora Unesp, 2015. Tomo II.

SEGALA, Marco. Fisiologia e metafisica in Schopenhauer. Rivista di filosofia, v. LXXXV, n. 1, p. 35-66, abr. 1994.

. Auf den Schultern eines Riesen. Arthur Schopenhauer als Student Johann Friedrich Blumenbachs. In: STOLLBERG, Jochen; BÖKER, Wolfgang (Orgs). “... die Kunst zu sehn". Arthur Schopenhauers Mitschriften der Vorlesungen Johann Friedrich Blumenbachs (1809-1811). Göttingen: Universitätsverlag Göttingen, 2013.

SILVA, Gabriel Valladão. Cogito ergo volo: para uma fundamentação epistemológica da metafísica da vontade schopenhaueriana. Dissertação de mestrado. Campinas: Universidade Estadual de Campinas, 2015.

SORIA, Ana Carolina Soliva. Orgânico e inorgânico em "Sobre a vontade na natureza”. Revista Voluntas: Estudos sobre Schopenhauer, v. 3, n. 1 e 2, p. 194202, 2012.

ZENTNER, Marcel. 'Das Ziel alles Lebens ist der Tod'. Schopenhauer und Freuds Todestrieb. Archiv für Geschichte der Philosophie, v. 75, p. 319-339, 1993.

Recebido em: 03-09-2018

Aceito para publicação em: 02-11-18 